\title{
An Excursion to the Museum (Wycieczka do muzeum)
}

\author{
Author: Tadeusz Różewicz
}

First Published: 1961

Translations: Różewicz' works have been translated into 49 languages. English: An Excursion to the Museum (2002); the text is part of anthologies and collected works in many languages.

\begin{abstract}
About the Author: Tadeusz Różewicz (1921-2014) was a poet, playwright, novelist, screenwriter, essayist and translator, who experienced the "fulfilled apocalypse" of World War II and the Holocaust. When his education was cut short in 1939 by the outbreak of World War II, he worked temporary jobs to support his family, and fought for two years in the Polish underground Home Army (Armia Krajowa). It was at this time that he started writing patriotic poems and poetic prose, and working as editor for the underground newspaper Czyn Zbrojny. Różewicz studied history of art at the Jagiellonian University in Cracow (1945-1949), where he became involved with the neo-avantgarde „Grupa Krakowska”. In 1950, Różewicz made a sojourn to Hungary, and lived in Wrocław from 1968 until his death. His extensive work, which was shaped by the hardship of war, the occupation, and the Holocaust, made him a widely recognised author as well as a highly regarded moral authority.
\end{abstract}

Further Important Publications: Niepokój (1947, Faces of Anxiety/Restlessness; poems); Opadty liście z drzew (1955, The Leaves Have Fallen from The Trees; short stories); Poezje zebrane (1957, Collected Poems); Przerwany egzamin (1960, The Interrupted Exam; short stories); Kartoteka (1960, The Card Index; play); Grupa Laokoona (1961, The Laocoon Group; play); Swiadkowie albo nasza mała stabilizacja (1962, The Witness; play); Niepokój. Wybór wierszy 1945-1961 (1963, Faces of Anxiety/Restlessness: Selected Poems); Stara kobieta wysiaduje (1968, The Old Woman Broods; play); Śmierć w starych dekoracjach (1970, Death amidst Old Stage Props; novel); Przygotowanie do wieczoru autorskiego (1971, Preparations for an Author's Evening; essays and sketches); Biate matżeństwo (1975, White Marriage; play); Conversation with a Prince and Other Poems (1982, selection in English); Pułapka (1982, The Trap; play); Płaskorzeźba (1991, Bas-Relief; poems); Zawsze fragment. Recycling (1996, Always Fragment. Recycling; poems).

\section{Content and Interpretation}

Różewicz wrote An Excursion to the Museum in 1959, taking inspiration from his visit to Auschwitz and from the official propaganda on Auschwitz at that time - a time when the former extermination camp was a "principal destination of school groups and workplace groups” (Kosicka, 2016, p. 126). The resulting text, published in the

Ә Open Access. (๑) 2021 Hans-Christian Trepte, published by De Gruyter. (cc) BY-NC-ND This work is licensed under a Creative Commons Attribution-NonCommercial-NoDerivatives 4.0 License. https://doi.org/10.1515/9783110671056-039 
Polish weekly Nowa Kultura in 1961, is an homage to Tadeusz Borowski ( $\rightarrow$ A Farewell to Maria). Beginning with its parodic title, the text demonstrates a new approach to language, expression and style in Holocaust literature. With the help of the "prosaicisation of lyrical speech" (Vogler, 1949, p. 4), the author conveys his disgust for the spectacle of Holocaust tourism. In a manner reminiscent of Borowski's deadpan tone, Różewicz describes crowds of cheerful, colourfully dressed tourists heading casually to the museum as a sightseeing destination. In search of entertainment, the visitors "repeat sentimental clichés and quote propaganda slogans" (Kosicka, 2016, p. 126) conveyed by stereotypes of Polish literature (Sienkiewicz, Kraszewski), and - in confrontation with the "banality of evil" (Hannah Arendt) people can be seen "eating plums and sandwiches" and to "meander among the display cases". Without any self-reflection, they ask such questions as "Sir, where are the gallows?" and "Where's the hair?” (Różewicz, 2002, p. 1). A tour presentation provides "matter-of-fact information" about "numbers, kilograms of clothing, women's hair, thousands of shaving brushes, combs and bowls, and millions of burned bodies” (Kosicka, 2016, p. 126). Różewicz's story depicts a superficial response to the Holocaust, a departure from "normal" life to which the visitors will soon return. "The people who visited the museum were taking seats in compartments. Little was said about the museum" (Różewicz, 2002, p. 1.). Together with two other small works - Massacre of the Boys (Rzeź chłopców) and The Braid (Warkoczyk), An Excursion to the Museum has become a fixture in Polish coursework and part of the canon of Polish studies. Różewicz's "reportage” stands furthermore in close kinship with Zofia Nałkowska's $\rightarrow$ Medallions and Tadeusz Borowski's works on the Holocaust and concentration camps, and it has given inspiration to such literary accomplishments as Mikuláš Kováč's collection of poems $\rightarrow$ The Earth Under Your Feet.

\section{Main Topics and Problems}

The motifs of war and the atrocities of the Holocaust have been present in Różewicz's works since his literary debut, as has the poet's quest to find an adequate language to convey the horrors of war and genocide, so as to give adequate expression to his firsthand experiences. After returning home safely (his brother Janusz was executed by the Gestapo), and in response to Adorno's well-known assessment of literature after Auschwitz, Różewicz emphasises the importance of the task that awaits him, namely "To create poetry after Auschwitz" (as he writes in the poem "I Did Espy a Marvellous Monster"), and "to reconstruct the human being bit by bit”, taking ethics as a source of his creative work. With his ascetic style, and by means of facts both brutal and banal, as well as an element of the grotesque, Różewicz has become one of the "most respected innovators and stylists in modern European history" (Fowler, 2013, p. 1). With the passage of time, the Holocaust has come to be regarded in the broader global context of genocide and the constant existential threat to human existence. This is why rereadings of Różewicz's work so often lead to new interpretations. As a self-confessed "prophet of the waste", Różewicz also anticipated the ecological crisis, as in his play 
An Old Woman Broods (Stara kobieta wysiaduje). In his work Recycling, Różewicz presents a collection of histories, sensual and brutal - of both "human and animal flesh" -, that trace his experience of war and of writing, as well as the close relationship between words and waste, forcing his readers to reflect on the "living forms" (Hopkin, 2001, p. 4) through which a new art comes into being.

\section{Cited Works}

Fowler, S. J. (2013). Maintenant \#97 - Tadeusz Różewicz. 3:AM Magazine, 24.05., available at: https://www.3ammagazine.com/3am/maintenant-97-tadeusz-rozewicz/ [Accessed: 20.02.2020]. Hopkin, J. (2001). Poetry of Laughter and Survival. The Guardian. 19.05., p. 4. Kosicka, J. (2016). A Dream by Felicja Kruszewska. And An Excursion to the Museum by Tadeusz Różewicz. London: Routledge. Vogler, H. (1949). Rękawiczka czyli o wstydliwości uczucia. Odrodzenie, 2(2), pp. 3-6. Różewicz (2002). An Excursion to the Museum. London: Routlege.

\section{Further References}

Browarny, W. (2013). Tadeusz Różewicz and Modern Identity in Poland since the Second World War. Kraków: Universitas. Burkot, S. (1987). Tadeusz Różewicz. Warszawa: Wydawnictwo Szkolne i Pedagogiczne. Catlin, J. (2020). Why Visit Auschwitz: Rereading Tadeusz Różewicz. UCB Comparative Literature Undergraduate Journal. Available at: https://www.academia.edu/6137362/Why_Visit_Auschwitz_Rereading_Tadeusz_R\% C3\%B3\%C5\%BCewicz [Accessed: 19.02.2020]. Dąbrowski, M. (1990). Tadeusz Różewicz. In: Literatur Polens 1944-1985. Berlin: Volk und Welt. Drewnowski, T. (1990). Walka o oddech. O pisarstwie Tadeusza Różewicza. Warszawa: Wydawnictwa Artystyczne i Filmowe. Romanska, K. (2014). Trip to the Museum. In: K. Romanska, M. Cioffi, eds., The Posttraumatic Theatre of Grotowski and Kantor: History and Holocaust in ,Akropolis‘ and ,The Dead Class‘. London, New York: Anthem Press. pp. 126-128. Scholze, D. (1989). Tadeusz Różewicz. In: D. Scholze, ed., Zwischen Vergnügen und Schock. Polnische Dramatik im 20. Jahrhundert. Berlin: Henschel Verlag, pp. 180-215. Sokoloski, R. (2013). Tadeusz Różewicz: A Return Excursion to the Museum. Slavonica, 19(2), pp. 95-97. Vogler, H. (1972). Tadeusz Różewicz. Warszawa: PIW. Wyka, K. (1977). Różewicz parokrotnie. Warszawa: PIW. Zechenter, K. (2014). Tadeusz Różewicz obituary. Poet and Dramatist Haunted by the Second World War and the Suffering of Poland. The Guardian, 04.05., available at: https://www.theguardian.com/books/ 2014/may/04/tadeusz-rozewicz [Accessed: 19.02.2020].

HCT 